\title{
The effect of metyrosine on oxidative gastric damage induced by ischemia/reperfusion in rats. Biochemical and histopathological evaluation ${ }^{1}$
}

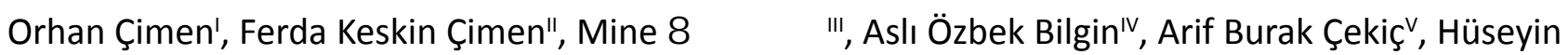
Eken $^{\mathrm{VI}}$, Zeynep Süleyman ${ }^{\mathrm{VII}}$, Yasin Bilgin ${ }^{\mathrm{VIII}}$, Durdu Altuner ${ }^{\mathrm{IX}}$

'Assistant Professor, Department of General Surgery, Faculty of Medicine, Erzincan University, Turkey. Scientific, intellectual, conception and design of the study; manuscript preparation.

"Assistant Professor, Department of Pathology, Faculty of Medicine, Erzincan University, Turkey. Histopathological examinations, manuscript writing.

I'Full Professor, Department of Biochemistry, Faculty of Pharmacy, Atatürk University, Erzurum, Turkey. Acquisition, analysis and interpretation of data.

IVAssistant Professor, Department of Pharmacology, Faculty of Medicine, Erzincan University, Turkey. Technical procedures, statistics analysis, manuscript writing.

${ }^{v}$ Assistant Professor, Department of General Surgery, Faculty of Medicine, Karadeniz Technical University, Trabzon, Turkey. Scientific and intellectual content of study.

${ }^{V}$ 'MD, Department of General Surgery, Mengücek Gazi Training and Research Hospital, Erzincan, Turkey. Technical procedures, manuscript preparation.

VIIMSc, Department of Pharmacology, Faculty of Health Sciences, Erzincan University, Turkey. Manuscript preparation.

VIIIMD, Department of Emergency, Mengücek Gazi Training and Research Hospital, Erzincan, Turkey. Manuscript preparation.

${ }^{1 X}$ Associate Professor, Department of Pharmacology, Faculty of Medicine, Erzincan University, Turkey. Statistics analysis, critical revision, final approval.

\section{Abstract}

Purpose: To investigate the effect of metyrosine against I/R induced gastric damage in rats. Methods: Eighteen albino Wistar male rats were divided into groups; gastric I/R (GIR), 50 $\mathrm{mg} / \mathrm{kg}$ metyrosine+gastric I/R (MGIR), and sham (SG) groups. $50 \mathrm{mg} / \mathrm{kg}$ metyrosine was given to the MGIR group, and distilled water was given to the GIR and SG groups by the oral gavage. After 30 minutes, $25 \mathrm{mg} / \mathrm{kg}$ thiopental sodium was injected intraperitoneally. Ischemia was achieved for 1 hour by clamping the celiac artery of the MGIR and GIR groups, then reperfusion was achieved for 3 hours. After that, animals were killed with $50 \mathrm{mg} / \mathrm{kg}$ thiopental. Biochemical and histopathological examinations performed on the gastric tissues. Results: Metyrosine decreased the MDA and MPO and the increased the TGSH and SOD. In addition, it reduced inflammation by suppressing the decrease of COX-1 and the increase of COX-2. Histopathologically, metyrosine decreased symptoms caused by I/R such as mucosal necrosis, hemorrhage, edema, PMNL infiltration, and dilated congested blood vessels. Conclusions: Metyrosine prevented the I/R induced oxidative stress in the gastric tissue. Metyrosine may be beneficial for gastric I/R injury.

Key words: Reperfusion Injury. Ischemia. Stomach. alpha-Methyltyrosine. Rats. 


\section{Introduction}

Gastric ischemia/reperfusion (I/R) injury can occur during a variety of surgical procedures and due to a number of pathological conditions such as vascular rupture, gastrointestinal disease, and hemorrhagic shock ${ }^{1}$. Prolonged subjection of the tissue to ischemia can lead to irreversible damage in the tissue. For this reason, the tissue undergoes reperfusion. However, reperfusion of the ischemic tissue paradoxically results in a much more severe damage to the tissue than ischemic injury alone $^{2}$. Excessive free oxygen radicals (FOR) forming from the molecular oxygen abundantly introduced by arterial blood to the ischemic tissue during reperfusion is held responsible for reperfusion injury ${ }^{3}$. These increased FORs can lead to tissue lipid peroxidation, causing cellular death and mucosal damage $e^{4}$. It is known that inflammatory reaction, as well as oxidative stress, plays an important role in the pathogenesis of gastric $I / R$ injury ${ }^{5}$. The inflammation in gastric $I / R$ injury is usually hemorrhagic and leads to mucosal erosion ${ }^{6}$. These data obtained from literature show that antioxidant and antiinflammatory drugs may be beneficial for gastric $\mathrm{I} / \mathrm{R}$ injury. The human body has natural antioxidant and antiinflammatory mechanisms against oxidants. However, none of the natural antioxidant systems have the ability to protect against the attack of oxidants induced by $I / R^{7,8}$. For this reason, antioxidant and antiinflammatory agents have been tried and found effective against gastric $\mathrm{I} / \mathrm{R}$ injury ${ }^{9}$. However, there are few satisfactory methods for the clinical treatment of gastric $I / R$ injury. Therefore, research on the treatment of gastric $I / R$ injury is ongoing. Metyrosine, the protective effect of which against gastric I/R injury we will try in this study, is an inhibitor of the tyrosine enzyme that participates in the synthesis of catecholamine ${ }^{10}$. There are studies reporting the antioxidant activity of metyrosine ${ }^{11}$.
Metyrosine has been reported to protect gastric tissue from indomethacin and ethanol damage and to inhibit the cyclooxygenase-2 (COX2) enzyme to produce an antiinflammatory effect ${ }^{12}$. The presence of antiulcer, antioxidant, and antiinflammatory effects of metyrosine suggests that it may protect the stomach against $I / R$ injury. The literature shows that the effect of metyrosine on gastric $I / R$ injury has not been investigated. For this reason, the aim of our study is to biochemically and histopathologically investigate the effect of metyrosine on $\mathrm{I} / \mathrm{R}$-induced gastric damage in rats.

\section{Methods}

Animal experiments were performed in accordance with the National Guidelines for the Use and Care of Laboratory Animals and were approved by the local animal ethics committee of Atatürk University, Turkey (Ethics Committee no. 77040475-000-E.1700191783).

A total of 18 male albino Wistar rats weighing between 245 and 265 grams were used in the experiment. All of the rats were obtained from the Atatürk University Medical Experimental Practice and Research Center. The animals were fed and sheltered under appropriate conditions at normal room temperature $\left(22^{\circ} \mathrm{C}\right)$ in groups before the experiment.

The animals were divided into groups, including the group with induced gastric ischemia/reperfusion (GIR), the $50 \mathrm{mg} / \mathrm{kg}$ metyrosine+gastric ischemia/reperfusion (MGIR) group, and the group that underwent a sham operation (SG).

\section{Chemical substances}

The metyrosine used in the experiment was obtained from Sigma Chemical (Munich, Germany), and thiopental sodium was obtained from I.E ULAGAY (Turkey). 


\section{Experimental procedure}

For this experiment to be carried out, $50 \mathrm{mg} / \mathrm{kg}$ of metyrosine was administered by oral route with a catheter to the MGIR animal group. The GIR and SG groups were given distilled water as a solvent at the same volume and with the same method. 30 minutes after metyrosine and distilled water were administered, $25 \mathrm{mg} / \mathrm{kg}$ thiopental sodium was intraperitoneally (ip) injected into all rat groups and they were made to inhale xylazine at appropriate intervals to achieve anesthesia. After the injection of the thiopental sodium, the rats were kept waiting for the appropriate period for the surgery to come. The period when the animals are stationary in the supine position is considered a suitable period for surgical intervention ${ }^{8}$. During this period, laparotomy was performed on the rats with a midline incision of $2.5 \mathrm{~cm}$ in length under sterile conditions. To induce ischemia/ reperfusion lesions, the celiac arteries of the MGIR and GIR animal groups were clamped with a clip and ischemia was created for 1 hour. The opened abdominal region of the SG group was closed by suturing without clipping their celiac arteries. Then, the clip was removed and reperfusion was achieved for 3 hours ${ }^{13}$. At the third hour of reperfusion, all animals were killed with high dose $(50 \mathrm{mg} / \mathrm{kg})$ thiopental anesthesia. Biochemical and histopathological examinations were then carried out on the gastric tissue removed from the killed animals.

\section{Biochemical analyses}

\section{Measurement of oxidative stress parameters}

Rat's stomach were kept in $-80^{\circ} \mathrm{C}$ for 3 days to determine tissue superoxide dismutase (SOD) enzyme activity and total glutathione (GSH) and malondialdehyde (MDA) levels. To prepare the tissue homogenates, the gastric tissues were ground with liquid nitrogen in a mortar; $0.1 \mathrm{~g}$ was weighed and then treated with $4.5 \mathrm{ml}$ of an appropriate buffer. The tissues were treated with HEPES buffer for SOD and RIPA buffer for MDA measurement and then homogenized on ice by an Ultra-Turrax homogenizer at $9500 \mathrm{rpm}$. Homogenates were filtered and centrifuged by using a refrigerator centrifuge at $4^{\circ} \mathrm{C}$. These supernatants were then used to determine SOD and MDA levels with highly sensitive ELISA kits (Cayman Chemical, Cell Biolabs OxiSelect ${ }^{\mathrm{TM}}$ TBARS Assay STA-330 Kit, respectively). Kits were specifically designed for rat cytokines, and all measurements were performed according to the manufacturers' instructions. Cytokine assays for each animal and its correlated control were run in the same lot. All assays were carried out at room temperature in dublicate.

SOD activity

SOD are metalloenzymes that catalyze the dismutation of the superoxide anion to molecular oxygen and hydrogen peroxide and thus form a crucial part of the antioxidant defense mechanism. Cayman's Superoxide Dismutase Assay Kit utilizes a tetrazolium salt for detection of superoxide radicals generated by xanthine Oxidase and hypoxanthine. One unit of SOD is defined as the amount of enyzme needen to exhibit $50 \%$ dismutation of the superoxide radical. Monitor the absorbance at 440-460 $\mathrm{nm}$ using a plate reader ${ }^{14}$.

MDA analysis

MDA is a naturally occuring product of lipid peroxidation. Lipid peroxidation is a wellestablished mechanism of cellular injury in both plants and animals and is used an indicator of oxidative stress in cells and tissues. The measurement of Thiobarbituric Acid Reactive Substances (TBARS) is a well-established method for Screening and monitoring lipid peroxidation. The MDA-TBA adduct formed by the reaction of MDA and TBA under high temperature $\left(90-100^{\circ} \mathrm{C}\right)$ and acidic conditions is measured colorimetrically at $530-540 \mathrm{~nm}$ at an excitation wave length ${ }^{15}$. 


\section{$\underline{\mathrm{tGSH} \text { analysis }}$}

The GSH levels in the gastric tissues were measured with the method created by Sedlak and Lindsay ${ }^{16}$. For this assay, the gastric tissue homogenized in $2 \mathrm{~mL}$ of $50 \mathrm{mM}$ Tris- $\mathrm{HCl}$ buffer containing $20 \mathrm{mM}$ EDTA and $0.2 \mathrm{M}$ sucrose, $\mathrm{pH}$ 7.5. The homogenate was centrifuged at $4200 \mathrm{rpm}$ for $40 \mathrm{~min}$ at $4{ }^{\circ} \mathrm{C}$, and then the supernatant was used to determine GSH using 5,5-dithiobis (2-nitrobenzoic acid). Absorbance was measured by spectrophotometric method at $412 \mathrm{~nm}$. Tissue protein levels were determined by the method of Bradford ${ }^{17}$. The activity of SOD and the levels of GSH and MDA in the tissues were expressed as $\mathrm{U} / \mathrm{mg}$ protein, $\mu \mathrm{M} / \mathrm{mg}$ protein (nmol/mg protein) and $\mu \mathrm{M} / \mathrm{mg}$ protein $(\mathrm{nmol} / \mathrm{mg}$ protein, respectively.

\section{Measurement of COX activity}

Preparation of reagents for COX activity analysis The analysis buffer was prepared by diluting $3 \mathrm{~mL}$ of the analysis buffer in $27 \mathrm{~mL}$ of HPLC-grade water. The hem reagent was prepared by diluting $88 \mu \mathrm{L}$ of the hem solution in $1.912 \mathrm{~mL}$ of the previously prepared analysis buffer. The arachidonic acid solution was prepared by adding $100 \mu \mathrm{L}$ of $\mathrm{KOH}$ to $100 \mu \mathrm{L}$ of arachidonic acid, vortexing, and diluting with $1.8 \mathrm{~mL}$ of HPLC-grade water. The other substances used were the COX standard, colorimetric substrate, DuP697 (COX-2 inhibitor), and SC-560 (COX-1 inhibitor), which are available in commercial kits.

\section{Procedures}

In a 96-well microplate, the wells for the samples, which are blind for each sample, inhibitors and standards were labeled. The samples were removed from the deep freezer and allowed to defrost. To prepare the blind sample, a quantity of $50 \mu \mathrm{L}$ from each sample was transferred into a microcentrifuge tube. The tubes were than boiled in a water bath for $5 \mathrm{~min}$ and centrifuged at $8000 \mathrm{rpm}$ for $1 \mathrm{~min}$.
The supernatant was used as the blind sample. Than $150 \mu \mathrm{L}$ of the analysis buffer and $10 \mu \mathrm{L}$ of the hem solution were transferred into each COX standard, sample, and blind sample well.

Next, $10 \mu \mathrm{L}$ of the standard, sample, and active samples were added to the wells. Each of the inhibitor wells received $140 \mu \mathrm{L}$ of the analysis buffer, $10 \mu \mathrm{L}$ of the hem solution, $10 \mu \mathrm{L}$ of the sample, and $10 \mu \mathrm{L}$ of the SC 560 solution. The plates were rotated in a plate rotator for a few seconds and then incubated at $25^{\circ} \mathrm{C}$ for $5 \mathrm{~min}$. After incubation, first, $20 \mu \mathrm{L}$ of the colorimetric substrate and then $20 \mu \mathrm{L}$ of the arachidonic acid solution were added into each well. After rotating the plate for a few seconds and incubating it at $25^{\circ} \mathrm{C}$ for 5 min, the absorbances at a wavelength of 590 $\mathrm{nm}$ were read. Using the formula given below, the total COX activity and the activities of COX1 and COX-2 were calculated. After calculating the total COX activity of each sample, the COX activities of the SC 560 treated samples were calculated using the same formula to identify the COX-2 activities. The COX-2 activity was subtracted from the total COX activity to determine the COX-1 activity. The enzyme quantity that oxidized $1 \mathrm{nmol}$ of TMPD at $25^{\circ} \mathrm{C}$ in 1 min was accepted as one enzyme unit, and the enzyme activity in the tissues is provided as enzyme units per gram of wet tissue ${ }^{18}$

$$
\begin{gathered}
\text { Total } \\
\text { COX } \\
\text { activity }
\end{gathered}=\frac{\Delta \mathrm{A} 590 /}{5 \mathrm{~min}} \times \frac{\begin{array}{c}
0.21 \mathrm{~mL} \\
\text { Total } \\
\text { volume }
\end{array}}{0.00826 \mu \mathrm{M}^{-1}} \times \frac{\begin{array}{c}
0.01 \mathrm{~mL} \\
\text { Specimen } \\
\text { volume }
\end{array}}{2 *}
$$

* The results are divided by two because $2 \mathrm{~mol}$ of TMPD are required to reduce $\mathrm{PGG}_{2}$ to $\mathrm{PGH}_{2}$.

The activity of COX in the tissue was expressed as $\mathrm{nmol} / \mathrm{min} / \mathrm{mg}$ protein $(\mathrm{U} / \mathrm{mg}$ protein) 


\section{Statistical analyses}

The results obtained from the experiments were expressed as "mean value \pm standard deviation" ( $x \pm$ SEM). The significance level of the difference between groups was determined using a one-way ANOVA. Subsequently, Fisher's post-hoc LSD (least significant differences) test was performed. All statistical operations were performed on the "SPSS for Windows, 20.0" statistics software and a value of $p<0.05$ was considered significant.

\section{- Results}

\section{Biochemical results}

Results of analysis of oxidative stress parameters in gastric tissue

As seen in Figure $1 \mathrm{~A}$, the amount of MDA in the $1 / R$-induced group is significantly increased compared to the healthy group. There is a statistically significant difference between the group given metyrosine and the I/R group ( $p<0.0001$ ). I/R damage also reduced the tGSH level compared to the healthy group. There is a statistically significant difference between the metyrosine group and the $I / R$ group (Fig. 1B).

The $I / R$ procedure increased MPO activity in gastric tissue. Metyrosine administration reduced MPO activity to a level close to that of the healthy group and there is no statistical difference between the healthy group and the metyrosine group $(p>0.05)$. There is, however, a statistically significant difference between the metyrosine group and the I/R group (Fig. 1C).

I/R injury reduced SOD activity in gastric tissue and there is a significant difference between the $1 / R$ group and the metyrosine group $(p<0.001)$. Metyrosine increased SOD activity and brought it to a level close to that of the healthy group (Fig. 1D).
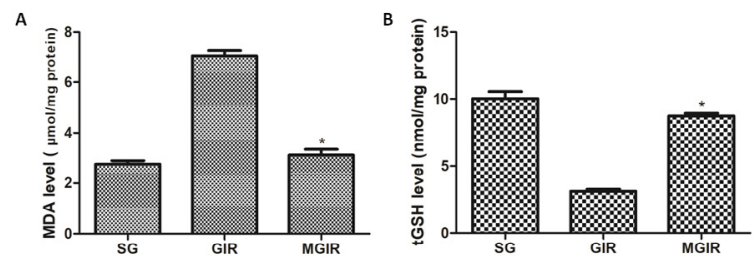

C
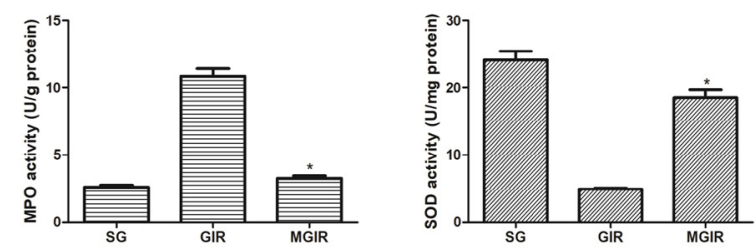

Figure 1 - The effects of metyrosine on MDA (A), tGSH levels (B), MPO (C) and SOD activity (D) in the gastric tissue. Bars are mean \pm SEM. MGIR group is compared with GIR group. ${ }^{*} p<0.0001$.

\section{Results of COX-1 and COX-2 activity assays}

COX-1 activity is reduced in the $1 / R$ group compared to the healthy group, and there is a significant difference between them. While there is a significant difference $(p<0.001)$ between the metyrosine and $I / R$ groups, no statistically significant difference $(p<0.05)$ was found between the metyrosine group and the healthy group (Fig. 2A). In Figure $2 \mathrm{~B}$, it is can be seen that the I/R procedure has significantly increased COX-2 activity. Again, metyrosine administration has reduced this increase to values close to those of the healthy group. While there is no statistical difference between the metyrosine group and the healthy group, there is a significant difference between the metyrosine and $\mathrm{I} / \mathrm{R}$ groups $(\mathrm{p}<0.001)$.
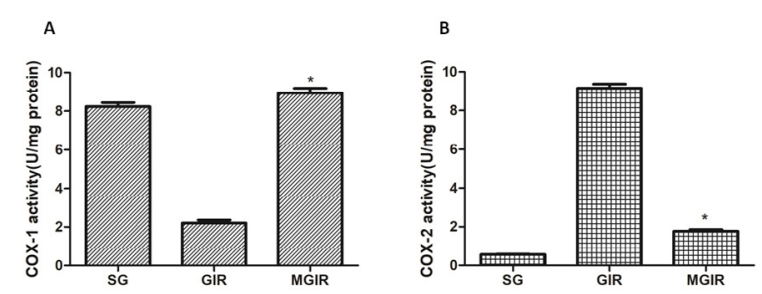

Figure 2 - The effects of metyrosine on COX-1 (A) and COX-2 (B) aktivity in the gastric tissue. Bars are mean $\pm S E M$. MGIR group is compared with GIR group. ${ }^{*} p<0.001$. 


\section{Histopathological results}

The mucosal gland structures, muscularis mucosa, submucosa, and the muscularis propria of the healthy group are observed as being normal under a light microscope (Fig. 3A). Severe mucosal necrosis, hemorrhage, edema, PMNL infiltration, and dilated congested blood vessels are observed in the gastric tissue with induced I/R (Fig. 3B). On the other hand, no histopathological findings other than dilated congested blood vessels were observed in the gastric tissue treated with metyrosine (Fig. 3C).

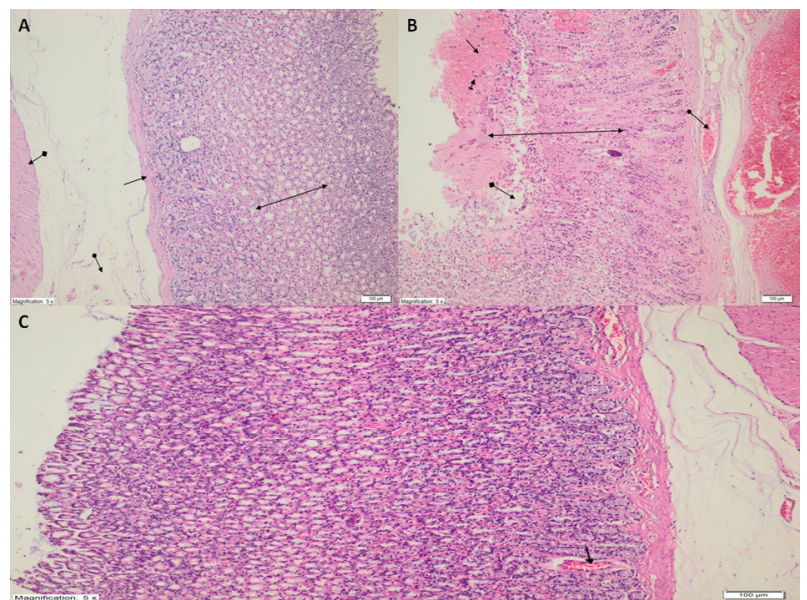

Figure 3 - A. Light microscopic view of the SG group. Normal gland structures (two-sided arrow), muscularis mucosa (straight arrow), submucosa (arrow with circle at the tip), and muscularis propria (arrow with square at the tip) are microscopically observed in the mucosa of the healthy gastric tissue (HE x100). B. Light microscopic view of the GIR group. Mucosal necrosis (two-sided arrow), hemorrhage (straight arrow), edema (arrow with square), PMNL infiltration (arrow with a line at the tip), and dilated congested blood vessels (arrow with circle at the tip) are seen in the gastric tissue with induced ischemia/reperfusion (HE x100). C. Light microscopic view of the MGIR group. No histopathological findings were observed in gastric tissue treated with metyrosine, other than dilated congested blood vessels (HE x100).

\section{Discussion}

In this study, the effect of metyrosine, a tyrosine hydroxylase enzyme inhibitor, on gastric I/R injury was examined biochemically and histopathologically. Oxidative stress occurring due to I/R was evaluated with oxidant (MDA, MPO) and antioxidant (GSH, SOD) parameters, and the inflammatory response was evaluated based on tissue COX-1 and COX-2 enzyme activities. Gastric I/R injury is a common clinical problem that can lead to acute mucosal lesions in the stomach ${ }^{19}$. Ischemia can weaken the gastric mucosal barrier, increase acid back-diffusion, and damage the gastric mucosa. After reperfusion, FORs are produced and can lead to cell lipid peroxidation, causing cell death and mucosal damage ${ }^{4}$. MDA is the final product of lipid peroxidation. Cui et al. ${ }^{20}$ observed in their study that the MDA level in the gastric mucosa increased after $I / R$, and that endogenous $\mathrm{H}_{2} \mathrm{~S}$ suppressed this increase. In our study, MDA levels increased significantly in the GIR group, while metyrosine suppressed this increase.

Recent studies suggest that $I / R$ injury is a complex pathological process that begins with the absence of oxygen in the tissue, continues with the oxidant/antioxidant balance changing in favor of oxidants, and expands with an inflammatory response ${ }^{21}$. As can be understood from our experiment results, a significant increase was observed in the activity of MPO, which is known as an inflammation marker, in the gastric tissue with induced I/R. The acute inflammatory response is characterized by induction of cytokines, neutrophil infiltration and the production of FORs that cause tissue damage ${ }^{22}$. Studies have shown that MPO activity, an indicator of neutrophil infiltration, is elevated with I/R injury ${ }^{23}$. In our study, the increasing MPO activity was observed to decrease with the administration of metyrosine. This suggests that the pathophysiology of $I / R$ injury is associated with inflammatory responses.

In our study, it was found that the tGSH amount in the gastric tissue of the GIR group, the MDA and MPO levels of which were 
measured to be significantly high compared to the healthy group and the metyrosine group, had significantly decreased compared to these groups. As is known, GSH is a major endogenous antioxidant produced by mammalian cells, which prevents the damage caused by FORs in key cell components ${ }^{24}$. Studies show that GSH depletion due to I/R in the gastrointestinal system is associated with FOR accumulation and accelerates tissue damage ${ }^{7}$.

Another endogenous parameter used to evaluate antioxidant activity is the SOD enzyme. There are studies in the literature indicating that the gastric $\mathrm{I} / \mathrm{R}$ procedure leads to a decrease in SOD activity ${ }^{25}$. In addition to the tGSH level that decreased with I/R, SOD activity came to the level of the healthy group with the effect of metyrosine in this study. Our experiment results and this information obtained from the literature suggest that metyrosine prevented the impairment of the oxidant-antioxidant balance in favor of oxidants in the gastric tissue with induced I/R.

Theinflammatoryprocessisanimportant mechanism that plays a role in the formation of organ damage due to I/R. Previous studies have assessed COX activity in inflammatory tissue to elucidate the antiinflammatory mechanism of metyrosine ${ }^{12}$. As is known, COX-2 inhibition is held responsible for the antiinflammatory effects of NSAIDs and COX-1 inhibition is held responsible for gastrointestinal side effects ${ }^{26}$. There are studies in the literature showing that COX-2 is expressed in pathophysiological events in gastric and other tissues ${ }^{27}$. In our study, the antiinflammatory effect of metyrosine was assessed with COX activity. It was observed that COX-1 activity inhibited due to $\mathrm{I} / \mathrm{R}$ increased with the administration of metyrosine, and that increased COX-2 activity approached the values of the healthy group by being inhibited by metyrosine. No studies investigating the effect of metyrosine on gastric I/R damage were found in the literature. However, metyrosine has been reported to protect gastric tissue from indomethacin and ethanol damage ${ }^{12}$. Our experiment results show that metyrosine changes the COX-1/COX-2 balance in favor of COX-1 in gastric tissue with I/R.

The effect of metyrosine on gastric $I / R$ injury was also examined histopathologically. Our experiment results show that histopathological findings correspond to biochemical findings.

Previous studies have shown that microscopic changes such numerous erosions, spillage of superficial cells, necrosis, hemorrhages in the mucosal layers, inflammation, and neutrophil aggregation occur in gastric tissue with the I/R procedure, and that administration of gallic acid reduces these symptoms ${ }^{28}$. In our study, metyrosine had a protective effect on gastric tissue by preventing histopathological symptoms such as necrosis, hemorrhage, and edema that developed in the stomach due to I/R injury.

Considering that oxidative stress and the inflammatory process are major contributors to $\mathrm{I} / \mathrm{R}$ injury, numerous studies have been conducted to investigate antioxidant and antiinflammatory agents for the mitigation of $\mathrm{I} / \mathrm{R}$ related damage and their efficacies have been demonstrated ${ }^{29}$. Ahiskalioğlu et al. ${ }^{30}$ suggested in their study that metyrosine was more effective than metoprolol in preventing oxidative stress created in the heart of rats with a single dose of ketamine. It has been shown that metyrosine, known to have both antiinflammatory effects and protective effects against tissue damage, is as effective as moxonidine for renal inflammation created by ureteral ligation $^{11}$.

\section{Conclusions}

It has been biochemically and histopathologically demonstrated that the $I / R$ procedure leads to oxidative stress accompanied by inflammation in gastric tissue. In addition, it has been found that metyrosine 
prevents gastric I/R injury through antioxidant and selective antiinflammatory activity. Considering our study and previous studies, it can be said that metyrosine is promising for the clinical treatment of ischemia/reperfusion injury, and for this reason our study is a guide for further research.

\section{References}

1. Mythen MG, Webb AR. Intraoperative gut mucosal hypoperfusion is associated with increased postoperative complications and cost. Intensive Care Med. 1994;20:99-104. PMID: 8201106.

2. Zimmerman BJ, Granger DN. Reperfusion injury. Surg Clin North Am. 1992;72:65-83. PMID: 1731390.

3. Collard CD, Gelman S. Pathophysiology, clinical manifestations, and prevention of ischemia-reperfusion injury. Anesthesiology. 2001;94:1133-8. PMID: 11465607.

4. Gou LS, Zhang L, Yin C, Jia G, Yin X, Zhuang $X, X u X$, Liu Y. Protective effect of L-citrulline against acute gastric mucosal lesions induced by ischemia-reperfusion in rats. Can J Physiol Pharmacol. 2011;89:317-27. PMID: 21619416.

5. Piper HM, Meuter K, Schafer C. Cellular mechanisms of ischemia-reperfusion injury. Ann Thorac Surg. 2003;75:S644-S8. PMID: 12607706.

6. Kwiecien S, Jasnos K, Magierowski $M$, Sliwowski Z, Pajdo R, Brzozowski B, Mach T, Wojcik D, Brzozowski T. Lipid peroxidation, reactive oxygen species and antioxidative factors in the pathogenesis of gastric mucosal lesions and mechanism of protection against oxidative stress - Induced gastric injury. J Physiol Pharmacol. 2014;65:613-22. PMID: 25371520.

7. Sasaki M, Joh T. Oxidative stress and ischemiareperfusion injury in gastrointestinal tract and antioxidant, protective agents. J Clin Biochem Nutr. 2007;40:1-12. PMID: 18437208.

8. Demiryilmaz I, Turan MI, Kisaoglu A, Gulaboglu M, Yilmaz I, Suleyman $H$. Protective effect of nimesulide against hepatic ischemia/reperfusion injury in rats: Effects on oxidant/antioxidants, DNA mutation and COX-1/COX-2 levels.
Pharmacol Rep. 2014;66:647-52. PMID: 24948067.

9. Bilbao J, Garciaalonso I, Portugal V, Barcelo P, Ortiz J, Mendez J. Antioxidant drugs as therapeutic agents in experimental reperfusion injury. Rev Esp Enferm Dig. 1991;80:237-41. PMID: 1805888.

10. Nasrallah HA, Donnelly EF, Bigelow LB, Rivera-Calimlim L, Rogol A, PotkinS, Rauscher FP, Wyatt RJ. Inhibition of dopamine synthesis in chronic schizophrenia. Clinical ineffectiveness of metyrosine. Arch Gen Psychiatry. 1977;34:649-55. PMID: 17374.

11.Yigiter M, Yildiz A, Polat B, Alp HH, Keles ON, Salman AB, Suleyman $H$. The protective effects of metyrosine, lacidipine, clonidine, and moxonidine on kidney damage induced by unilateral ureteral obstruction in rats. Surg Today. 2012;42:1051-60. PMID: 22202971.

12. Albayrak A, Polat B, Cadirci E, Hacimuftuoglu A, Halici Z, Gulapoglu M, Albayrak F, Suleyman H. Gastric anti-ulcerative and anti-inflammatory activity of metyrosine in rats. Pharmacol Rep. 2010;62:113-9. PMID: 20360621.

13. Wada K, Kamisaki Y, Kitano M, Kishimoto Y, Nakamoto K, Itoh T. A new gastric ulcer model induced by ischemia-reperfusion in the rat: role of leukocytes on ulceration in rat stomach. Life Sci. 1996;59:PL295-301. PMID: 8913334.

14. Mattiazzi M, D'Aurelio M, Gajewski $C D$, Martushova K, Kiaei M, Beal MF, Manfredi G. Mutated human SOD1 causes dysfunction of oxidative phosphorylation in mitochondria of transgenic mice. J Biol Chem. 2002;277:29626-33. PMID: 12050154.

15.Armstrong $D$, Browne R. The analysis of free radicals, lipid peroxides, antioxidant enzymes and compounds related to oxidative stress as applied to the clinical chemistry laboratory. Adv Exp Med Biol. 1994;366:43-58. PMID: 7771281.

16.Sedlak J, Lindsay RH. Estimation of total, protein-bound, and nonprotein sulfhydryl groups in tissue with Ellman's reagent. Anal Biochem. 1968;25:192-205. PMID: 4973948.

17. Bradford MM. A rapid and sensitive method for the quantitation of microgram quantities of protein utilizing the principle of proteindye binding. Anal Biochem. 1976;72:248- 
54. PMID: 942051.

18. Kulmacz RJ, Lands WEM. Requirements for hydroperoxide by the cyclooxygenase and peroxidase-activities of prostaglandin- $\mathrm{H}$ synthase. Prostaglandins. 1983;25:531-40. PMID: 6410459.

19.LiY,Zhang JF, Zhang YM, MaXB. The protective effect of genistein postconditioning on hypoxia/reoxygenation-induced injury in human gastric epithelial cells. Acta Pharmacol Sin. 2009;30:576-81. PMID: 19349965.

20.Cui J, Liu L, Zou J, Qiao W, Liu H, Qi Y, Yan C. Protective effect of endogenous hydrogen sulfide against oxidative stress in gastric ischemia-reperfusion injury. Exp Ther Med. 2013;5:689-94. PMID: 23403765.

21.Suleyman B, Albayrak A, Kurt N, Demirci E, Gundogdu C, Aksoy M. The effect of etoricoxib on kidney ischemiareperfusion injury in rats: a biochemical and immunohistochemical assessment. Int Immunopharmacol. 2014;23:179-85. PMID: 25068826.

22.Ali AT, Al-Swayeh OA, Al-Rashed RS, AlMofleh IA, Al-Dohayan AD, Al-Tuwaijri AS. Role of oxygen-derived free radicals on gastric mucosal injury induced by ischemiareperfusion. Saudi J Gastroenterol. 1996;2:19-28. PMID: 19864838.

23.Kim CD, Hong KW. Preventive effect of rebamipide on gastric lesions induced by ischemia-reperfusion in the rat. J Pharmacol Exp Ther. 1995;275:340-4. PMID: 7562569.

24.Pompella A, Visvikis A, Paolicchi A, De Tata V, Casini AF. The changing faces of glutathione, a cellular protagonist. Biochem Pharmacol. 2003;66:1499-503. PMID: 14555227.

25.Cabeza J, Motilva V, Martin MJ, de la Lastra CA. Mechanisms involved in gastric protection of melatonin against oxidant stress by ischemia-reperfusion in rats. Life Sci. 2001;68:1405-15. PMID: 11388692.

26.Laudanno OM, Cesolari JA, Esnarriaga J, San Miguel $P$, Bedini OA. In vivo selectivity of nonsteroidal antiinflammatory drugs and gastrointestinal ulcers in rats. Dig Dis Sci. 2000;45:1359-65. PMID: 10961715.

27.Katori M, Majima M. Cyclooxygenase-2: its rich diversity of roles and possible application of its selective inhibitors. Inflamm Res. 2000;49:367-92. PMID: 11028754.

28. Mard SA, Mojadami S, Farbood Y, Gharib Naseri MK. The anti-inflammatory and anti-apoptotic effects of gallic acid against mucosal inflammation- and erosionsinduced by gastric ischemia-reperfusion in rats. Vet Res Forum. 2015;6:305-11. PMID: 26973766.

29.Mard SA, Azad SM, Ahangarpoor A. Protective effect of crocin on gastric mucosal lesions induced by ischemia-reperfusion Injury in rats. Iran J Pharm Res. 2016;15:939. PMID: 28228808.

30.Ahiskalioglu A, Ince I, Aksoy M, Ahiskalioglu EO, Comez M, Dostbil A, Celik M, Alp HH, Coskun R, Taghizadehghalehjoughi A, Suleyman B. Comparative Investigation of protective effects of metyrosine and metoprolol against ketamine cardiotoxicity in rats. Cardiovasc Toxicol. 2015;15:336-44. PMID: 25503950.

\section{Correspondence:}

Prof. Durdu Altuner

Department of Pharmacology, Faculty of

Medicine, Erzincan University

24100, Erzincan Turkey

Phone: 04462261818

durdualtuner@hotmail.com

Received: Nov 07, 2017

Review: Jan 05, 2018

Accepted: Feb 06, 2018
Conflict of interest: none

Financial source: none 


\section{Erratum}

Manuscript: The effect of metyrosine on oxidative gastric damage induced by ischemia/reperfusion in rats. Biochemical and histopathological evaluation.

Publication: Acta Cir Bras. 2018 Mar;33(3):259-267.

DOI: $10.1590 / \mathrm{s} 0102-865020180030000008$

On page 259 of the original publication, instead of this:

Orhan Çimen', Ferda Keskin Çimen", Mine Gülapoğlu'", Aslı Özbek Bilgin'v', Arif Burak Çekiç̧v, Hüseyin

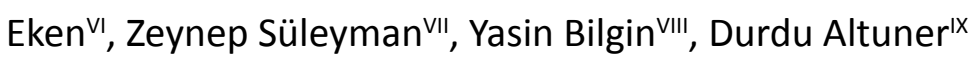

Consider this:

Orhan Çimen', Ferda Keskin Çimen", Mine Gülaboğlu'", Aslı Özbek Bilgin'”, Arif Burak Çekiç̧v, Hüseyin

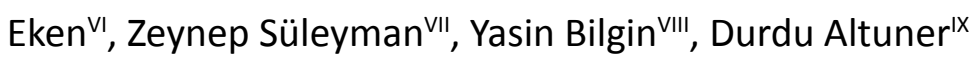

